\title{
Carcinoma of the Eyelid cN1 TNM Finding v7
}

National Cancer Institute

\section{Source}

National Cancer Institute. Carcinoma of the Eyelid cN1 TNM Finding v7. NCI Thesaurus. Code C88579.

Carcinoma of the eyelid with regional lymph node metastasis. (from AJCC 7th Ed.) 